\title{
Vaccination against encapsulated bacteria in humans: paradoxes
}

\author{
Weller Sandra , Reynaud Claude-Agnès * , Weill Jean-Claude * \\ Developpement du Systeme Immunitaire INSERM : U373, Université Paris Descartes - Paris V- 156 rue de Vaugirard, Paris,FR
}

* Correspondence should be adressed to: Claude-Agnès Reynaud <claude-agnes.reynaud@inserm.fr>

* Correspondence should be adressed to: Jean-Claude Weill <jean-claude.weill@inserm.fr>

\begin{abstract}
Infection with encapsulated bacteria can be prevented by vaccination with capsular polysaccharides, either plain or conjugated to a protein carrier. But results concerning these vaccinations raise several paradoxes. Polysaccharides from encapsulated bacteria are generally considered to be Tindependent antigens unable to trigger a T-dependent germinal center reaction, but strikingly, anti-polysaccharide antibodies are often mutated in humans. Polysaccharide-protein conjugate vaccines are able to induce a true T-dependent memory response with a rise in antibody titers and a switch to high affinity-IgG antibodies in children below 2 years of age, but neither the plain nor the conjugate vaccine can induce memory in older infants and adults. We propose some explanations to these paradoxes based on our recent observation that humans display a circulating splenic marginal zone B cell population with a pre-diversified immunoglobulin repertoire in charge of the immune response to $T$-independent vaccines.
\end{abstract}

MESH Keywords Antigens, T-Independent ; immunology ; B-Lymphocyte Subsets ; immunology ; B-Lymphocytes ; immunology ; Bacteria ; immunology ; Bacterial Capsules ; immunology ; Bacterial Infections ; prevention \& control ; Germinal Center ; immunology ; Humans ; Immunologic Memory ; immunology ; Intestines ; immunology ; Models, Immunological ; Polysaccharides, Bacterial ; immunology ; Somatic Hypermutation, Immunoglobulin ; immunology ; Spleen ; immunology ; T-Lymphocytes ; immunology ; Vaccination ; Vaccines, Conjugate ; immunology

Author Keywords encapsulated bacteria ; polysaccharides ; conjugated vaccine ; T-independent response

The impact of diseases generated by encapsulated bacteria has been underlined in many contexts and it is estimated that they are responsible for millions of children's deaths each year [1]. Nevertheless, when looking at the abundant literature on immune responses to encapsulated bacteria after vaccination by either plain or conjugated capsular polysaccharide vaccines, some paradoxes emerge which we would like to discuss.

\section{Paradox 1}

It is generally accepted that bacterial capsular polysaccharides (CPS) are TI antigens that trigger specific B cells residing in the splenic marginal zone to secrete antibodies with opsonophagocytic properties against these bacteria [2]. In rodents in which these responses have been mostly studied, immunization do not induce an extensive proliferation within B cell follicles, neither the formation of germinal centers, and are for most of them taken care by unmutated germline antibodies [3-5]. In humans on the contrary, the splenic marginal zone contains B cells with mutated Ig receptors [6-8] and mutated antibodies are raised in responses to encapsulated bacteria, these mutations being responsible for the antibodies avidity for the immunizing antigen [9, 10]. In all species, these TI responses do not trigger any memory, the B cells engaged being able very rapidly to switch isotype and to secrete large amount of antibodies. These plasma cells can remain in the organism for various lengths of time, after which the response wanes out $[11,12]$. To account for the presence in humans of mutated antibodies during a T-independent immune response that cannot normally trigger a cognate T-B dependent germinal center reaction, the classical explanation put forward by authors is that such responses are in fact taken care by bona fide memory B cells that have been primed by a previous encounter with the pathogen, either during an infection or by silent carriage [13-15]. These memory B cells would then eventually reside in the splenic marginal zone where they could acquire marginal zone B cell surface markers [16-18]. This explanation requires that during this natural priming which must have occurred in each case analyzed so far, the polysacharidic capsules from the pathogen are somehow linked to a protein moiety in order to drive the response into the classical germinal center-dependent memory B cell pathway.

\section{Paradox 2}

Children below 2 years do not respond to plain CPS vaccines but they do respond when the CPS are conjugated to a protein carrier ( Table 1 and Box 1). Moreover these conjugate vaccines will induce a memory response with a rise of antibody titer after several rounds of immunization and a booster response several months later [21-24]. Surprisingly, in older infants and in adults, the same conjugate vaccine does not induce a memory response but a response similar to the one obtained with the plain CPS preparation [25-28], even though the response to the conjugate appears in some cases more robust [29-30].

\section{A proposed explanation}


We have shown that humans display a circulating marginal zone B cell population which is involved in TI response and which diversifies its Ig receptor in the absence of cognate T-B interactions. These conclusions are based on the following experimental facts:

- Hyper-IgM patients with either CD40L or CD40 deficiency do not have germinal centers and possess a population of circulating IgM ${ }^{+}$ $\mathrm{IgD}^{+} \mathrm{CD} 27^{+} \mathrm{B}$ cells with a mutated Ig receptor, in the complete absence of switched memory B cells. In both types of patients the frequency of Ig mutations observed in these cells is similar to the one observed in controls, although the number of $\operatorname{IgM}{ }^{+} \operatorname{IgD}{ }^{+} \mathrm{CD}_{2} 7^{+}$ blood cells is in general lower in the patients as compared to normal children. The absence of CD40 or CD40L may alter B cell development by hampering the network of cytokines interactions involving dendritic cells, activated $\mathrm{T}$ cells and natural killer cells. Nevertheless, the fact that these patients never display any $\mathrm{CD} 27^{+}$switched B cell indicate that the $\operatorname{IgM}^{+} \operatorname{IgD}{ }^{+} \mathrm{CD} 27^{+} \mathrm{B}$ cells present are not produced in some cryptic germinal center structures, but rather belong to a separate population.

- Phenotypic analysis and gene expression profiling in normal individuals indicate that human splenic marginal zone B cells are, as opposed to rodents [31], recirculating in the blood.

- After vaccination with a non-conjugated pneumococcal vaccine, blood and splenic $\operatorname{IgM}^{+} \operatorname{IgD}{ }^{+} \mathrm{CD}_{2} 7^{+} \mathrm{B}$ cells are specifically mobilized in this T-independent response. This response is taken care of by B cells carrying mutated antibodies prior to immunization. Upon expansion of these cells in the splenic marginal zone during the week following vaccination, the hypermutation process is reactivated.

- The blood $\operatorname{IgM}^{+} \operatorname{IgD}{ }^{+} \mathrm{CD} 27^{+} \mathrm{B}$ cell population starts to expand after birth. It is well expanded and mutated in children around one year of age, an age at which toddlers do not respond to T-independent antigens, thus strongly suggesting that diversification results at this stage from a developmental program and not from an immune response.

Our conclusion from these preliminary investigations is, as already proposed in our first report [32], that this so-called memory IgM ${ }^{+}$ $\mathrm{IgD}^{+} \mathrm{CD} 27^{+} \mathrm{B}$ cell population, which represents $10-30 \%$ of B cells in blood and spleen, belonged to a different pathway of differentiation and was linked to the response against TI-antigens [33]. A similar conclusion was reached by R. Carsetti and her colleagues in a recent report, based on their study on the responding capacity asplenic or splenectomized patients to T-independent pneumococcal antigens [34].

The model we propose offers obviously another solution to paradox 1 without having to involve an obligatory primary infection or carriage. The B cells involved in the response are already pre-diversified and can undergo another round of hypermutation after stimulation by the immunizing antigen. These B cells, which are already in a pre-activated state, do not possess any properties attributed to memory B cells. However, being constantly triggered by TI antigens, they could account for most of the so-called « natural » IgM antibodies present in the circulation [35].

In order to explain paradox 2 we would like to propose that before two years of age, in the absence of a functional splenic marginal zone, CPS vaccines conjugated to a protein carrier will trigger naive follicular B cells and drive them into a germinal center-dependent reaction including affinity maturation and memory B cell generation. After two years, the now functional splenic marginal zone will sequester polysaccharidic preparations from encapsulated bacteria, whether they are conjugated to a protein carrier or not, thus explaining why a similar marginal zone type of response without any memory characteristics is obtained with both the plain and the conjugated CPS vaccines. Strikingly, bone marrow transplanted patients, which cannot respond to pneumoccocal CPS until approximately 2 years after the transplant, respond to the conjugate vaccine like normal toddlers below 2 years by generating a clear memory response [36, 37]. Thus in both situations in which the splenic marginal zone is not functional, do we see an uncoupling between the response to the plain and the conjugated CPS preparation.

There may be direct clinical consequences to our propositions that can be tested. Effectively, patients undergoing a splenectomy are usually vaccinated by the plain or the conjugated vaccines prior to the operation. According to our scheme these patients should mount, like toddlers, a memory response if vaccinated by the conjugated vaccine after splenectomy. The same result should be obtained with asplenic patients.

Moreover, having observed that the B cells engaged in these responses are already well developed and mutated in blood at an age at which children cannot respond to the plain CPS vaccine, and taking into account that it will be challenging to conjugate the serotypes of all encapsulated bacteria (e.g. there are 90 serotypes for Streptoccocus pneumoniae and only 11 have been conjugated at this moment), it is tempting to speculate that plain vaccines in conjunction with the appropriate adjuvant specific for these cells may be able to trigger a protective response in toddlers below 2 years. It is clear that such a result if possible would be a life-saving progress in underdeveloped countries. 
There remain many unsolved questions concerning these cells and the response against encapsulated bacteria. The splenic marginal zone being obviously a complex lymphoid niche, is there a contribution in humans, even minor, of bona fide memory B cells to TI responses? What are the cells that sequester CPS antigens after 2 years, whether there are in their natural or vaccine form? Does this occur in the splenic marginal zone or also in blood through specific DC which can bring them to the spleen, and what are the specific receptors involved? [38, 39]

How and where do marginal zone B cells diversify their Ig receptor throughout life? During the first two years of life in infants one can study blood $\operatorname{IgM}^{+} \operatorname{IgD}{ }^{+} \mathrm{CD} 27^{+} \mathrm{B}$ cells as they develop and diversify their Ig receptors, prior to any immune response. Thereafter encounter with external TI antigens in the mature environment of the splenic marginal zone will trigger their effector function, i.e. the production of antibodies What pre-activates these cells and drive their final differentiation remains an open question. This pre-diversification step could take place in the splenic marginal zone and in marginal zone-like regions in lymph nodes and Peyer's patches [40]. It could alternatively occur in isolated B lymphoid follicles along the gut, as has been described for other species [41] (see below). A similar pre-activated stage has been described for NK T cells [42], and, similarly to them, pre-activation of marginal zone B cells could be driven by self or bacterial commensal antigens. For both these cellular populations, NKT and marginal zone B cells which are intermediate between the innate and adaptive immune system, this pre-activated stage may explain why they react very rapidly upon challenge by external bacterial antigens [12].

\section{Looking at other B cell immune systems}

GALT (gut-associated lymphoid tissues) species, as opposed to bone marrow species, do not use ongoing rearrangement in the bone marrow to generate B cell diversity. They include a large number of mammalian species studied today (sheep, rabbits, cattle, pigs, etc...) and have been named so because they generate their B cell pre-immune repertoire by post-rearrangement diversification processes such as hypermutation and/or gene conversion in gut-associated lymphoid tissues [43, 44]. This pre-diversification step is antigen-independent although gut bacterial antigens provide the mitotic stimuli permitting the intense proliferation of these cells in GALT follicles [45, 46]. Moreover, in all these species there is only one window of B cell production and diversification that occurs during several months after birth, the peripheral B cell compartment being then installed for the whole life of the animal. The obvious advantage of this mode of generation of the B cell repertoire by gene conversion and hypermutation, which target all three CDRs, is the variety of specificities and affinities produced, allowing these species to also respond to T-independent antigens with a large range of binding capacities.

Despite obvious differences between GALT B cells and human marginal zone B cells, our data imply that humans have most probably conserved for one arm of their B cell system the strategies used by GALT species to diversify their pre-immune repertoire. This strategy which differs from the one used by follicular B cells, allows the generation of a robust immune response against life threatening infections by encapsulated bacteria.

Box 1

History

"It occurred to us that if the pneumococcus polysaccharide could be combined with a foreign protein it should be possible to produce a conjoined carbohydrate-protein antigen capable of stimulating the formation of type-specific pneumococcus antibodies in the animal body. Provided the specificity of the original carbohydrate has not been too greatly altered either through chemical manipulation, or through the introduction of new molecular groupings, one should obtain on immunization with such a "synthetic antigen", antibodies which would be identical in specific action with those produced by immunization with the intact bacterial cells."

Walter F. Goebel and Oswald T. Avery J. Exp. Med. 54, 431-436 (1931)

The first conjugate vaccine was developped by Goebel and Avery [19]. In trying to understand how the polysaccharides of the pneumococcal capsule were involved in the virulence of the organism, Avery a few years later identified DNA as the support of genetic information, in the famous bacterial transformation experiment with Colin M. McLeod and Maclyn McCarty [20].

\section{Ackowledgements:}

We thank Capucine Picard for critical reading of the manuscript.

\section{References:}

- 1. Giebink GS 2001; The prevention of pneumococcal disease in children. N Engl J Med. 345: 1177- 1183

- 2. Harms G 1996; In vitro complement-dependent binding and in vivo kinetics of pneumococcal polysaccharide TI-2 antigens in the rat spleen marginal zone and follicule. Inf Immun. 64: 4420- 4225

- 3. Dammers PM 2000; Most marginal zone B cells in rat express germline encoded Ig VH genes and are ligand selected. J Immunol. 165: $6156-6169$

- 4. Maizels N , Bothwell A 1985; The T-cell-independent immune response to the hapten NP uses a large repertoire of heavy chain genes. Cell. 43: 715- 720

- 5. De Vinuesa CG 1999; T-independent type 2 antigens induce B cell proliferation in multiple splenic sites, but exponential growth is confined to extrafollicular foci. Eur J Immunol. 29: 1314- 1327 
- 6. Dunn-Walters DK 1995; Analysis of mutations in immunoglobulin heavy chain variable region genes of microdissected marginal zone (MGZ) B cells suggests that the MGZ of human spleen is a reservoir of memory B cells. J Exp Med. 182: 559- 66

- 7. Tangye SG 1998; Identification of functional human splenic memory B cells by expression of CD148 and CD27. J Exp Med. 188: 1691- 1703

- 8. Tierens A 1999; Marginal-zone B cells in the human lymph node and spleen show somatic hypermutations and display clonal expansion. Blood. 93: 226- 234

- 9. Lucas AH , Reason DC 1999; Polysaccharide vaccines as probes of antibody repertoires in man. Immunol Review. 171: 89- 104

- 10. Zhou J 2004; Somatic hypermutation and diverse immunoglobulin gene usage in the human antibody response to the capsular polysaccharide of Streptococcus pneumoniae type 6B. Infect Immun. 72: 3505- 3514

- 11. Zandvoort A, Timens W 2002; The dual function of the splenic marginal zone: essential for initiation of anti-TI-2 responses but also vital in the general first-line defense against blood-borne antigens. Clin Exp Immunol. 130: 4- 11

- 12. Lopez-Carvalho T, Kearney JF 2004; Development and selection of marginal zone B cells. Immunol Rev. 197: 192- 205

- 13. Lucas AH 2001; Combinatorial library cloning of human antibodies to Streptococcus pneumoniae capsular polysaccharides: variable region primary structures and evidence for somatic mutation of Fab fragments specific for capsular serotypes 6B, 14, and 23F. Infect Immun. 69: 853- 864

- 14. Barington T 1996; The progeny of a single virgin B cell predominates the human recall B cell response to the capsular polysaccharide of Haemophilus influenzae type b. J Immunol. 157: 4016- 4027

- 15. Baxendale HE 2000; Immunogenetic analysis of the immune response to pneumococcal polysaccharide. Eur J Immunol. 30: 1214- 1223

- 16. Liu YJ 1988; Memory B cells in T-cell-dependent antibody responses colonize the splenic marginal zones. Eur J Immunol. 18: 355- 362

- 17. Vinuesa CG 2003; Recirculating and germinal center B cells differentiate into cells responsive to polysaccharide antigens. Eur J Immunol. 33 : 297- 305

- 18. Shih TAY 2002; Role of BCR affinity in T cell-dependent antibody responses in vivo. Nat Immunol. 3: 570- 575

- 19. Avery OT , Goebel WF 1931; Chemo-immunological studies on conjugated carbohydrate-protein. V The immunological specificity of an antigen prepared by combining the capsular polysaccharide of type III pneumococcus with foreign protein. J Exp Med. 54: 437- 447

- 20. Avery OT 1944; Studies on the chemical nature of the substance inducing transformation of Pneumococcal types: induction of transformation by a desoxyribonucleic acid fraction isolated from Pneumococcus type III. J Exp Med. 79: 137- 158

- 21. Borrow R 2001; Influence of prior meningococcal C polysaccharide vaccination on the response and generation of memory after meningococcal C conjugate vaccination in young children. J Infect Dis. 184: 377- 380

- 22. Greenberg DP 1995; Enhanced antibody responses in infants given different sequences of heterogeneous Haemophilus influenzae type b conjugate vaccines. J Pediatr. 126: 206- 211

- 23. Richmond P 2001; Ability of 3 different meningococcal C conjugate vaccines to induce immunologic memory after a single dose in UK toddlers. J Infect Dis. 183: 160163

- 24. Rennels MB 1998; Safety and immunogenicity of heptavalent pneumococcal vaccine conjugated to CRM 197 in United States infants. Pediatrics. 101: 604- 611

- 25. Goldblatt D 2002; Natural and vaccine-induced immunity and immunologic memory to Neisseria menigitidis serogroup C in young adults. J Infect Dis. 185 : $397-400$

- 26. Cryz SJ 1988; Immunization with a Pseudomonas aeruginosa immunotype 5 O polysaccharide-toxin A conjugate vaccine: effect of a booster dose on antibody level in humans. Infect Immun. 56: 1829- 1830

- 27. Kamboj KK 2003; Significant variation in serotype-specific immunogenicity of the seven-valent Streptococcus pneumoniae Capsular polysaccharide-CRM ${ }_{197}$ conjugate vaccine occurs despite vigorous T cell help induced by the carrier protein. J Infec Dis. 187: 1629- 1638

- 28. Shelly MA 1997; Comparison of pneumococcal polysaccharide and $\mathrm{CRM}_{197}$ conjugated pneumococcal oligosaccharide vaccines in young and elderly adults. Infect Immun. 65: 242- 247

- 29. Baker CJ 1999; Safety and immunogenicity of capsular polysaccharide-tetanus toxoid conjugate vaccines for group B streptococcal types Ia and Ib. J Infect Dis. 179: 142150

- 30. Guttormsen HK 2002; Type III group B streptococcal polysaccharide induces antibodies that cross react with streptococcus pneumoniae type 14. Infect Immun. 70: 17241738

- 31. MacLennan ICM 1982; The lymphocytes of splenic marginal zones: a distinct B-cell lineage. Immunol Today. 3: 305- 307

- 32. Weller S 2001; CD40-CD40L independent Ig gene hypermutation suggests a second B cell diversification pathway in humans. Proc Natl Acad Sci USA. 98 : $1166-1170$

- 33. Weller S 2004; Human blood IgM "memory" B cells are circulating splenic marginal zone B cells harboring a pre-diversified immunoglobulin repertoire. Blood.

- 34. Kruetzmann S 2003; Human immunoglobulin M memory B cells controlling Streptococcus pneumoniae infections are generated in the spleen. J Exp Med. 197: 939- 945

- 35. Bernasconi NL 2002; Maintenance of serological memory by polyclonal activation of human memory B cells. Science. 298: $2199-2202$

- 36. Guinan EC 1994; Polysaccharide conjugate vaccine responses in bone marrow transplant patients. Transplantation. 57: 677- 684

- 37. Molrine DC 2003; Donor immunization with pneumococcal conjugate vaccine and early protective antibody responses following allogeneic hematopoietic cell transplantation. Blood. 101: 831- 836

- 38. Gijtenbeek TB 2002; Marginal zone macrophage express a murine homologue of DC-SIGN that captures blodd-borne antigens in vivo. Blood. 100: 2908 - 2916

- 39. Balazs M 2002; Blood dendritic cells interact with splenic marginal zone B cells to initiate T-independent immune responses. Immunity. 17: 341 - 352

- 40. Spencer J 1998; Human marginal-zone B cells. Immunol Today. 19: 421- 426

- 41. Hamada H 2002; Identification of multiple isolated lymphoid follicles on the antimesenteric wall of the mouse small intestine. J Immunol. 168: 57- 64

- 42. Brigl M 2003; Mechanism of CD1d-restricted natural killer T cell activation during microbial infection. Nat Immunol. 4: 1230 - 1237

- 43. Weill JC , Reynaud CA 1998; GALT versus bone marrow models of B cell ontogeny. Dev Comp Immunol. 22: 379 - 385

- 44. Reynaud C-A, Weill J-C Editor: Vainio O , Imhof BA 1996; Postrearrangement diversification processes in Gut-associated lymphoid tissues. Current Topics in Microbiology and Immunology. 212: 7- 15 Springer Verlag;

- 45. Reynaud CA 1995; Hypermutation generating the sheep immunoglobulin repertoire is an antigen-independent process. Cell. 80: $115-25$

- 46. Lanning D Editor: Alt FW , Honjo T, Neuberger MS 2004; Immunoglobulin genes and generation of antibody repertoires in higher vertebrates: a key role for GALT. Molecular Biology of B cells. 433- 448 Elsevier Science Ltd; 


\section{Figure 1}

A proposed scheme for the response to PS vaccines, plain or coupled to a protein carrier. Round shapes represent B cells and irregular ones, cells involved in antigen capture (macrophages, dendritic cells,...).

\section{Spleen}

Immature I absent splenic marginal zone

(children below 2 years.

bone marrow transplanted patients

splenectomized and asplenic individuals)

antigen response to protein-coupled

PS-antigens in germinal centers:

memory response

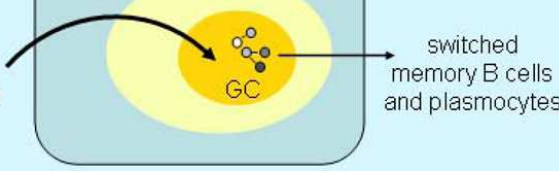

Fonctional splenic marginal zone PS-antigen (plain or coupled) trapping in marginal zone:

immediate T-indendent response. no memory response

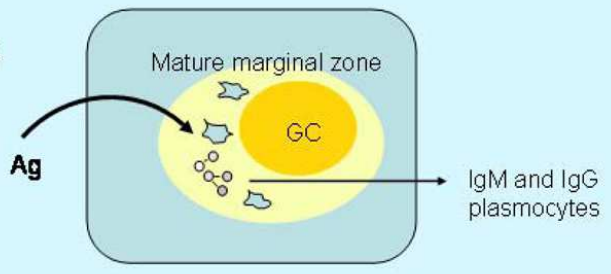


Table 1

Examples of plain polysaccharide vaccines and polysaccharide-protein conjugate vaccines

\begin{tabular}{|c|c|c|c|c|c|}
\hline Vaccines & & Manufacturer & $\begin{array}{c}\text { Bacterial } \\
\text { target }\end{array}$ & Capsular polysaccharides (CPS) included in vaccine & Carrier Protein \\
\hline \multirow{2}{*}{$\begin{array}{l}\text { PLAIN POLYSACCHARIDE } \\
\text { VACCINES }\end{array}$} & $\begin{array}{l}\text { PNEUMOVAX } \\
\circledR 23 \\
\text { PNEUMO 23® } \\
\text { PNEUMUNE® }\end{array}$ & $\begin{array}{c}\text { Merck } \\
\text { Aventis } \\
\text { Pasteur } \\
\text { Wyeth-Lederle }\end{array}$ & $\begin{array}{l}\text { Streptococcus } \\
\text { pneumoniae }\end{array}$ & $\begin{array}{l}\text { CPS from } 23 \text { pneumococcal serotypes: } 25 \mu \mathrm{g} / \text { dose of each type } 1,2,3,4,5,6 \mathrm{~B}, 7 \mathrm{~F}, 8,9 \mathrm{~N}, 9 \mathrm{~V}, 10 \mathrm{~A}, 11 \mathrm{~A}, 12 \mathrm{~F} \text {, } \\
14,15 \mathrm{~B}, 17 \mathrm{~F}, 18 \mathrm{C}, 19 \mathrm{~F}, 19 \mathrm{~A}, 20,22 \mathrm{~F}, 23 \mathrm{~F}, 33 \mathrm{~F}^{\mathrm{a}}\end{array}$ & \\
\hline & $\begin{array}{l}\text { HIB (not in use } \\
\text { anymore) }\end{array}$ & & $\begin{array}{l}\text { Haemophilus } \\
\text { influenzae } \\
\text { type }\end{array}$ & CPS from Haemophilus influenzae type b (polyribosyl-ribitol phosphate or PRP) & \\
\hline \multirow{4}{*}{$\begin{array}{l}\text { POLYSACCHARIDE-PROTEIN } \\
\text { CONJUGATE VACCINES }\end{array}$} & $\begin{array}{l}\text { PREVNAR® } \\
\text { (7-valent) }\end{array}$ & Wyeth-Lederle & $\begin{array}{l}\text { Streptococcus } \\
\text { pneumoniae }\end{array}$ & $\begin{array}{l}\text { CPS from } 7 \text { pneumococcal serotypes conjugated to a mutant diphtheria toxin: } 2 \mu \mathrm{g} / \text { dose of each type } 4,9 \mathrm{~V} \text {, } \\
14,18 \mathrm{C}, 19 \mathrm{~F}, 23 \mathrm{~F} \text { serotypes and } 4 \mu \mathrm{g} / \text { dose of type } 6 \mathrm{~B}\end{array}$ & $\begin{array}{l}\text { Diphtheria CRM } \\
197 \text { protein }\end{array}$ \\
\hline & $\begin{array}{l}\text { In clinical trial } \\
\text { (9-valent) }\end{array}$ & ${ }^{1}$ Wyeth-Lederle & $\begin{array}{l}\text { Streptococcus } \\
\text { pneumoniae }\end{array}$ & $\begin{array}{l}\text { CPS from } 9 \text { pneumococcal serotypes conjugated to a mutant diphtheria toxin: } 2 \mu \mathrm{g} / \text { dose of type } 1,4,5,9 \mathrm{~V} \text {, } \\
14,19 \mathrm{~F}, 23 \mathrm{~F} ; 2 \mu \mathrm{g} / \text { dose of type } 18 \mathrm{C} \text { and } 4 \mu \mathrm{g} \text { of type } 6 \mathrm{~B}\end{array}$ & $\begin{array}{l}\text { Diphtheria CRM } \\
\text { } 197 \text { protein }\end{array}$ \\
\hline & $\begin{array}{l}\text { In clinical trial } \\
\text { (11-valent) }\end{array}$ & $\begin{array}{l}\text { Aventis } \\
\text { Pasteur }\end{array}$ & $\begin{array}{l}\text { Streptococcus } \\
\text { pneumoniae }\end{array}$ & $\begin{array}{l}\text { CPS from } 11 \text { pneumococcal serotypes conjugated to diphtheria toxoid }(3,6 \mathrm{~B}, 14,18 \mathrm{C}) \text { or tetanus toxoid }(1,4, \\
5,7 \mathrm{~F}, 9 \mathrm{~V}, 19 \mathrm{~F}, 23 \mathrm{~F}): 1 \mu \mathrm{g} / \text { dose of type } 1,4,5,7 \mathrm{~F}, 9 \mathrm{~V}, 19 \mathrm{~F}, 23 \mathrm{~F}, 3 \mu / \text { dose of type } 3,14,18 \mathrm{C} \text { and } 10 \mu \mathrm{g} / \mathrm{dose} \text { of } \\
\text { type } 6 \mathrm{~B}\end{array}$ & $\begin{array}{l}\text { Tetanus and } \\
\text { diphtheria toxoids }\end{array}$ \\
\hline & Act-HIB $®$ & $\begin{array}{l}\text { Aventis } \\
\text { Pasteur }\end{array}$ & $\begin{array}{l}\text { Haemophilus } \\
\text { influenzae } \\
\text { type b }\end{array}$ & CPS from Haemophilus influenzae type b $(10 \mu \mathrm{g})$ conjugated to tetanus toxoid & Tetanus toxoid \\
\hline
\end{tabular}

